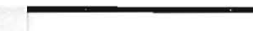

Resenha 


\title{
Giorgio AGAmBen E O HOMO SACER'
}

\author{
Marcos César Alvarez \\ Professor da UNESP/Marília \\ E-mail: mcalvarez@uol.com.br
}

\section{$E$}

m seu livro Homo Sacer: o poder soberano e a vida nua, agora publicado no Brasil ${ }^{2}$, o filósofo italiano Giorgio Agamben realiza uma reflexão extremamente instigante acerca da natureza do poder soberano na sociedade moderna e contemporânea. $\mathrm{O}$ autor busca mostrar como o que caracteriza o poder soberano no Ocidente é a politização crescente da "vida nua", da vida natural ou biológica tanto do corpo individual quanto da própria espécie. Para desenvolver essa tese polêmica, Agamben mobiliza um conjunto expressivo de pensadores - como Hannah Arendt, Karl Schmitt, Alain Badiou, Emile Durkheim, Walter Benjamin, entre muitos outros - mas suas idéias centrais desenvolvemse a partir de uma discussão específica realizada por Michel Foucault.

Em seus estudos sobre as práticas de poder na sociedade moderna, Michel Foucault identificou uma mutação decisiva na forma como o poder soberano no Ocidente lida com a vida e com a morte de seus súditos. Se durante muito tempo o poder soberano caracterizouse sobretudo como um poder de vida ou de morte, poder que causava a morte ou que deixava viver - já que consistia sobretudo numa instância de confisco, de extorsão de bens ou de trabalho -, no moderno Ocidente ocorrerá uma mutação profunda nos mecanismos de poder, de tal modo que as práticas de confisco serão suplantadas por práticas de incitação,

\footnotetext{
' AGAMBEN, Giorgio. Homo Sacer: o poder soberano e a vida nua. Belo Horizonte: UFMG, 2002. 207p.

${ }^{2} \mathrm{O}$ original italiano foi publicado em 1995.
} 
de reforço, de controle, de vigilância, de majoração e organização das forças submetidas. O poder estatal se voltará para gerir a vida em todos os seus aspectos, poder "produtivo", em oposição ao poder "negativo" voltado simplesmente para a possibilidade de causar a morte. Emerge assim um poder cujo principal objetivo não é mais matar, mas investir contra a vida, seja dos indivíduos, seja das populações. Inicia-se a era daquilo que Foucault (1999) chamará de "bio-poder".

Mas, ao passo que Foucault restringe a noção de biopoder, ao designar especificamente essas novas práticas que emergem no Ocidente a partir do século XVII, a proposta de Agamben em seu livro é muito mais ambiciosa. Para o filósofo italiano, Foucault teria acertado ao perceber que o evento decisivo na modernidade ocidental seria a inclusão da vida natural nos cálculos do poder estatal, mas não teria percebido que se trata de um longo processo histórico - tão antigo quanto a própria exceção soberana -, nem teria aprofundado a reflexão acerca da biopolítica como chave de compreensão da política moderna e contemporânea. Refletir justamente acerca do entrecruzamento do poder soberano, da vida nua e da biopolítica na história do Ocidente, condição essencial para a compreensão de nossa atualidade política, será este o objetivo perseguido pelo autor ao longo dos diversos capítulos que constituem o livro.

Se a noção de biopoder Agamben toma emprestada a Foucault, a noção de "vida nua" ele desenvolverá a partir da divisão, já presente na reflexão filosófica da Antigüidade clássica, entre vida natural e vida qualificada. Os gregos não possuíam um termo único para exprimir o sentido contemporâneo da palavra "vida". Serviam-se, em contrapartida, dos termos zoé - que exprimia a vida comum de todos os seres - e bíos - que indicava a forma de viver própria de um indivíduo ou comunidade. Enquanto zoé remetia à vida natural, bíos indicava uma vida qualificada, sendo a vida natural excluída do mundo da política, pois neste só poderia existir a vida politicamente qualificada (AGAMBEN, 2002, p.9-10).

Agamben desenvolve sua argumentação ao mostrar que o poder soberano no Ocidente nada mais teria feito do que explicitar e aprofundar o vínculo secreto que, paradoxalmente, se estabelece na simetria entre o poder soberano e a vida politicamente desqualificada. Pois se o soberano, na definição schmittiana, é aquele que decide sobre o estado 
de exceção, aquele que está simultaneamente dentro e fora do ordenamento jurídico, sua contrapartida simétrica é o indivíduo que é tomado apenas como vida natural, zoé sem bíos, alvo do poder soberano mas que não contaria com a proteção do ordenamento jurídico. E é numa figura do direito romano arcaico que Agamben encontra a metáfora mais acabada dessa condição da vida nua diante do poder soberano. Essa figura é a do homo sacer, expressão que designava aquele que foi julgado e condenado por um delito e que, devido a esta condenação, encontrava-se numa situação peculiar: ao mesmo tempo que não podia ser sacrificado, quem o matasse não seria condenado por homicídio. Assim, na simetria entre a figura do homo sacer e a do soberano, encontrase o segredo da compreensão do próprio espaço político da soberania:

[...] soberano e homo sacer apresentam duas figuras simétricas, que têm a mesma estrutura e são correlatas, no sentido de que o soberano é aquele em relação ao qual todos os homens são potencialmente homines sacri e homo sacer é aquele em relação ao qual todos os homens agem como soberanos (AGAMBEN, 2002, p.92).

Neste ponto, percebe-se uma das proposições mais perturbadoras que o autor parece propor à reflexão da Filosofia Política e das Ciências Sociais contemporâneas: se presenciamos na atualidade a inclusão praticamente total da vida nua, da vida natural ou biológica nos cálculos do poder do Estado, conseqüentemente todos encontramo-nos, ao menos potencialmente, na mesma condição do homo sacer diante da exceção do poder soberano. E se o desamparo do homo sacer é a chave para a compreensão da condição dos indivíduos e das populações na política atual, um espaço de experiências se apresenta como paradigmático das práticas biopolíticas: o campo de concetração.

Ao analisar a estrutura jurídico-política dos campos - e Agamben (2002, p.174) faz questão de lembrar que os primeiros campos de concetração criados na Alemanha não foram obra do regime nazista, mas sim dos governos social-democráticos - percebe-se que os indivíduos neles encarcerados eram integralmente despojados de seus direitos e prerrogativas, de tal modo que contra eles se podia cometer 
qualquer ato, tudo sendo verdadeiramente possível. A presença dessa estrutura jurídico-política, longe de constituir-se num caso excepcional, irá multiplicar-se num mundo dominado pela bio-política. Segundo o autor, podemos encontrá-la atualmente tanto nos campos de refugiados para imigrantes clandestinos na Itália, quanto nas zones d'attente dos aeroportos franceses, nos campos de estupro étnico na ex-Iuguslávia ou nos mais diferentes espaços em que indivíduos se encontram totalmente à mercê do poder soberano.

Estas e muitas outras teses, defendidas com extensa erudição pelo autor, abrem novas e incontornáveis questões no debate político contemporâneo, aceitemos ou não as suas posições mais polêmicas. Assim, por um lado, é difícil concordar com o descrédito manifesto por Agamben no que diz respeito à capacidade da democracia viabilizar formas de resistência efetiva às práticas biopolíticas. Por outro lado, alguém pode duvidar que, nos espaços mais diversos da cena contemporânea, seja nos campos de refugiados para imigrantes ilegais na Europa, seja na periferia das grandes cidades do planeta, seja nos países do Terceiro Mundo, não é o homo sacer que reencontramos, vidas nuas permanentemente em perigo diante do poder soberano?

\section{Referencias}

AGAMBEN, Giorgio. Homo Sacer: o poder soberano e a vida nua. Belo Horizonte: UFMG, 2002. 207p.

FOUCAULT, Michel. História da Sexualidade I: a vontade de saber. 13.ed. Rio de Janeiro: Graal, 1999. 